\title{
Transformational Leadership for Improving Teacher's Performance During the Covid-19 Pandemic
}

\author{
Erly Savitri*, Asep Sudarsyah \\ Administrasi Pendidikan \\ Universitas Pendidikan Indonesia, Bandung, Indonesia \\ Bandung, Indonesia \\ *erlyz.97@upi.edu
}

\begin{abstract}
This study aims to analyze the effect of transformational leadership for improving teacher's performance during the Covid-19 pandemic. This research is a sequential explanatory study using a combination research method (mixed methods) starting with the quantitative research stage and continuing with qualitative research. Data collection was carried out by observation, questionnaires and interviews. The questionnaire was tested using a Likert scale with regression techniques to 50 private teachers in Bandung. The results showed that transformational leadership improving teacher performance by $44 \%$. The higher implications of transformational leadership, the higher teacher's performance improving. The research evidence more clearly shows that transformational leadership can move followers to exceed expected performance. Transformational leadership gives rise to greater effort, commitment, and satisfaction of his subordinates. Improving teacher's teaching performance can be optimized by developing the capacity of the teacher (capacity building) itself. Capacity building is the process of improving the ability of knowledge and skills, as well as the attitudes and behavior of teachers in educational organizations. In this process it can certainly be done in various ways, both through competency-based education and training, clear career pattern development, all of which are to improve the performance of teachers in carrying out their duties. Therefore, capacity building is closely related to teacher's abilities, institutional capabilities, and organizational system capabilities. With improving teacher's performance, it is expected that educational goals can be achieved effectively and efficiently.
\end{abstract}

Keywords-Covid-19 pandemic, teacher's performance, transformational leadership

\section{INTRODUCTION}

Improving teacher performance is a critical requirement in improving the quality of education and producing superior quality graduates. Improving teacher performance can be done in various ways, among others, through the application of school-based management (school base management) to facilitate the Principal in updating teacher training and supervision creatively, planned, directed, and continuously, to encourage the achievement of increasing teacher performance [1]. Teacher performance is a series of process activities carried out by teachers in carrying out their duties and jobs to the maximum in accordance with their ability to achieve institutional goals. The ability of a teacher can be measured by his competence at the time of teaching. In carrying out their duties and jobs, teachers cannot be separated from various obstacles and work challenges, especially during the Covid-19 pandemic. Teacher performance will be optimal if it is integrated with school components, including school principals, school managers, and adequate work infrastructure. The principal as an education leader is responsible for the sustainable growth of teachers, he must be able to help teachers recognize community needs, help teachers build a curriculum according to student interests, needs and abilities. It must be able to stimulate teachers to develop teaching methods and procedures. He must be able to help teachers evaluate educational programs and student learning outcomes, he must also be able to assess the nature and abilities of teachers, so that the principal can help improve teacher abilities. To be able to carry out the above responsibilities, the principal must have the education and experience necessary for an educational leader [2].

The Covid-19 pandemic has had a major impact on education globally. During the Covid-19 pandemic, learning cannot be done face-to-face. This is what causes problems in learning, where learning that was originally carried out face-toface is replaced with online learning. Online learning environments usually require a reliable computer and internet connection. Teachers are required to be able to create and innovate in learning with limited conditions. The current condition in Indonesia is the lack of teacher skills in technology, supported by inadequate school infrastructure for online learning, the emergence of gaps between students from high-income households and students from low-income households both in the economic field and the ability to mastering technology. Beyond the educational challenges, lowincome families face an additional threat: the ongoing pandemic is expected to lead to a severe economic recession. Previous recessions have exacerbated child poverty with longterm consequences for children's health, well-being and learning outcomes [3]. 
The contribution of the principal as a leader is expected to be able to influence all people involved in the education process, especially teachers. The synergy of the principal's leadership, supported by good teacher performance, is expected to produce a good learning process and a balanced learning resource for student learning continuity by utilizing all available learning resources, including internet access and digital devices. One of the collaborative efforts carried out as an educational innovation initiative is to apply a transformational leadership model which is expected to have an impact on achieving goals and improving the quality of schools, especially during the COVID-19 Pandemic [2]

Yukl defines transformational leadership as an attempt to call upon the moral values of followers in an effort to raise their awareness of ethical issues and to mobilize their energy and resources to reform institutions [4]. With transformational leadership, followers feel trust, admiration, loyalty and respect for the leader, and they are motivated to do more than is initially expected of them. According to Bass [5], leaders change and motivate followers by (1) making them more aware of the importance of task results; (2) persuading them to prioritize the interests of their team or organization over personal interests, and (3) activate their higher needs.

Each leader basically has a different style of leadership called leadership style. The leadership style carried out by a leader in influencing the behavior of others can be influenced by the nature of the leader himself. The leadership style is one that can influence the behavior of organizational citizenship behavior of employees so that it has a positive impact on the organization. Examples of improving service quality and improving group performance. Behavior of organizational citizenship behavior employees will influence employee commitment in improving efficiency, effectiveness, and creativity in the organization through its contribution to resource transformation, innovation and adaptability.

Transformational leaders have a big influence and can inspire followers to exclude personal interests for the good of the organization. Transformational leaders pay great attention to their followers 'self-development needs, changing followers' awareness of the issues that exist within the organization and giving views on existing problems in new ways. In a study entitled Transformational leadership and performance outcomes: Analyzes of multiple mediation pathways, the results of a significant influence between transformational leadership on increasing organizational commitment have resulted. Transformational leadership influences job satisfaction and commitment affective organizations mediate the relationship between transformational leadership and task performance (task performance) of employees [6].

The definition of performance is as a result of the implementation of a work that provides an understanding that performance is an act or behavior of a person who can be directly or indirectly observed by others. Performance or work potential is a result of work achieved by a person in carrying out the tasks given to him based on skill, experience, and sincerity of fiber time [7].

According to Taylor [8], improving teacher performance must continue to be done at each level of education to improve the quality of education graduates to become quality human resources. It is believed that quality human resources are the most decisive factor in spurring growth in various fields of development. The availability of quality human resources will encourage the Indonesian people to be able to achieve excellence in producing quality works and be able to compete with other nations at the global level. However, the reality on the ground is that teacher performance has not yet shown the achievements as expected and still needs improvement and improvement.

Currently the world globally is facing the Covid-19 pandemic, this also has an impact on the world of education which has a direct effect on the sustainability of student learning in schools. As the COVID-19 Pandemic runs its course, many governments are implementing measures that limit the number of people congregating in public places. Such measures have disrupted the normal functioning of schools and universities. Because the duration of such measures has been extensive - and is likely to continue in some countries for a certain time until a vaccine becomes available - leaders of public and private education institutions have put in place alternative methods for students and teachers to continue with their lessons when attending school is not possible and are working on methods that will make schools fit for working in a safe environment [9]. With transformational leadership, it is hoped that it can improve the performance of teachers especially during the Covid-19 pandemic.

\section{METHODS}

The study was conducted on private school teachers in the city of Bandung. This research is a sequential explanatory study using a combination research method (mixed methods) starting with the quantitative research stage and continuing with qualitative research. The quantitative research stage was carried out by using regression techniques on 50 private teachers in the city of Bandung. The empirical data collected consisted of one independent variable, namely transformational leadership (X), with the dependent variable, namely teacher performance (Y). The instrument used for data collection at this stage was a Likert scale questionnaire which was arranged based on the indicators in the research variables. The primary data studied were data on transformational leadership and teacher performance.

\section{RESEARCH FINDINGS}

The purpose of this study is to see how strong the relationship between transformational leadership and teacher performance is, to find out how it impacts during the Covid-19 pandemic, and to get the optimal solution from this research.

Yukl describes several guidelines for transformational leadership [4], namely: (1) State a clear and attractive vision, 
(2) Explain how this vision can be achieved, (3) Act secretly and optimistically, (4) Show confidence in followers, (5) Using dramatic and symbolic actions to emphasize important values, (6) Leading by example, and (7) Authorizing people to achieve that vision.

Suwanto explains that a teacher must have four competencies, namely professional, pedagogic, personality, and social. Teachers must have the ability to carry out learning activities and assess the process and results of learning activities. Teachers must also have a good personality, and social attitudes towards their students and society. In detail, the performance indicators of teachers as administrators, teachers and mentors can be explained as follows [10]:

- Teacher performance as administrator

- Planning learning as outlined in the syllabus, lesson plan, learning scenarios, and others.

○ Administering learning processes and events.

- Administer the assessment process and learning outcomes.

○ Administering student learning presence.

- Teacher performance as a teacher

○ Teaching effectively based on learning objectives.

○ Delivering learning materials effectively, in accordance with learning objectives.

- Manage learning with the right strategies, methods and techniques.

- Evaluating learning progress objectively and effectively.

○ Carry out follow-up (follow-up) based on objective feedback.

- Teacher performance as a guide

- Motivate and direct students to achieve maximum learning goals.

$\circ \quad$ Helping and facilitating students to select and find learning resources / materials.

- Help overcome student learning difficulties.

- Help solve problems faced by students that cause learning difficulties.

The results of calculating $X$ Variable (Transformational Leadership) for improving value of Y Variable (Teacher's Performance) are as follows Table 1:
TABLE I. CASE PROCESSING SUMMARY

\begin{tabular}{|l|c|l|l|l|l|l|}
\hline \multirow{2}{*}{} & \multicolumn{6}{|c|}{ Cases } \\
\cline { 2 - 7 } & \multicolumn{2}{|c|}{ Valid } & \multicolumn{2}{c|}{ Missing } & \multicolumn{2}{|c|}{ Total } \\
\cline { 2 - 7 } & $\boldsymbol{N}$ & Percent & $\boldsymbol{N}$ & Percent & $\boldsymbol{N}$ & Percent \\
\hline $\begin{array}{l}\text { Transformational } \\
\text { Leadership }\end{array}$ & 50 & $100.0 \%$ & 0 & $0.0 \%$ & 50 & $100.0 \%$ \\
\hline Teacher's Performance & 50 & $100.0 \%$ & 0 & $0.0 \%$ & 50 & $100.0 \%$ \\
\hline
\end{tabular}

TABLE II. T-TEST RESULT

\begin{tabular}{|l|l|l|}
\hline & $\begin{array}{c}\text { Transformational } \\
\text { Leadership }\end{array}$ & $\begin{array}{c}\text { Teacher's } \\
\text { Performance }\end{array}$ \\
\hline Mean & 46,96 & 54,5 \\
\hline Variabce & 25,794 & 56,704 \\
\hline Observations & 50 & 50 \\
\hline Pearson correlation & 0,4402 & \\
\hline Hypothesized Mean Difference & 0 & \\
\hline df & 49 & \\
\hline t Stat & $-7,63$ & \\
\hline P(T<=t) one-tail & 3,5265 & \\
\hline t Critical one-tail & 1,6765 & \\
\hline P(T<=t) two-tail & 7,0531 & \\
\hline t Critical two-tail & 2,0095 & \\
\hline
\end{tabular}

Hypothesis Test acceptance criteria: Accept H0: if t count $\leq$ $\mathrm{t}$ table or $\mathrm{p}$-value $>$ alpha $(\alpha)$; Reject H0: If $\mathrm{t}$ count $>\mathrm{t}$ table or $\mathrm{p}$ value $\leq$ alpha $(\alpha)$. Results of the $t$ Test (in Table 2) in Transformational Leadership for Improving Teacher Performance are as follows: $\mid \mathrm{t}$ count $\mid=1.67655089$; $\mid \mathrm{t}$ table $=2.00957523$. Conclusion: $\mid \mathrm{t}$ count $\mid<\mathrm{t}$ table then the decision Accept H0. $1.67655089<2.00957523$ then the decision is Accept H0.

TABLE III. CORRELATIONS RESULT

\begin{tabular}{|c|c|l|l|}
\hline \multicolumn{2}{|c|}{} & $\begin{array}{c}\text { Transformational } \\
\text { Leadership }\end{array}$ & $\begin{array}{c}\text { Teacher's } \\
\text { Performance }\end{array}$ \\
\hline $\begin{array}{c}\text { Transformational } \\
\text { Leadership }\end{array}$ & $\begin{array}{c}\text { Pearson } \\
\text { Correlation }\end{array}$ & 1 & $.440 * *$ \\
\cline { 2 - 4 } & Sig. (2-tailed) & & .001 \\
\cline { 2 - 4 } & $\boldsymbol{N}$ & 50 & 50 \\
\hline $\begin{array}{c}\text { Teacher's } \\
\text { Performance }\end{array}$ & $\begin{array}{c}\text { Pearson } \\
\text { Correlation }\end{array}$ & $.440 * *$ & 1 \\
\cline { 2 - 4 } & Sig. (2-tailed) & .001 & 50 \\
\cline { 2 - 4 } & $\boldsymbol{N}$ & 50 & \\
\hline **. Correlation is significant at the 0.01 level (2-tailed). & \\
\hline
\end{tabular}

Table 3 shows that the Pearson Correlation $\mathrm{X}$ Variable (Transformational Leadership) for improving $\mathrm{Y}$ Variable (Teacher's Performance) is 0.440 . This shows that $\mathrm{X}$ Variable (Transformational Leadership) has implications for improving Y Variable (Teacher's Performance) by $44 \%$.

\section{DISCUSSIONS}

Transformational leaders change the personal values of subordinates to support the vision and goals of the organization by fostering an environment where relationships can be formed by building a climate of trust, organizational vision can be 
adequately conveyed. Indicators of transformational leadership are 1. subordinates feel trust, admiration, loyalty, and respect for their leaders. 2. subordinates are motivated to do more than expected, 3. make improvements and changes in the organization. Harms states that transformational leadership is a relationship of mutual encouragement and mutual respect that transforms followers into leaders and can convert leaders into moral agents", thus resulting in a transformation effect on both leaders and followers. Transformational leadership consists of four indicators, namely: 1. charisma or ideal influence, 2. inspirational leadership or motivation, 3. intellectual stimulation, and 4. individual consideration [8].

Law of the Republic of Indonesia Number 14 of 2005 Article 20 (a) describes Teachers and Lecturers. In carrying out professional tasks, teachers are obliged to plan learning, carry out a quality learning process, and assess and evaluate learning outcomes [11].

Ballou suggest that teacher performance is the ability and effort of teachers to carry out learning tasks as well as possible, starting from 1. planning learning programs, 2. implementing learning activities, and 3. evaluating learning outcomes. A good teacher's performance is the teacher's performance, which results in the achievement of learning objectives according to the standards set by the school. Millanowski, argues that a teacher can be said to have poor performance if the achievement is not satisfactory, because it is below the standard criteria that have been set. This means that the teacher has failed in carrying out their duties and responsibilities. Teacher performance is the teacher's effort in realizing his abilities in the form of attitudes, knowledge, and skills in 1 . planning, 2. implementing, 3. evaluating learning, and 4. following up on learning evaluation results effectively and efficiently to achieve maximum learning outcomes [8].

Many empirical studies have been conducted with respect to teacher competence and performance. The competence model provided by demonstrated that a teacher's performance depends on the teachers' knowledge, (comprised of subject matter and general pedagogy), which is directly linked to the teachers' competencies, characteristics, and attitudes [12].

The transformational leadership theory consists of four dimensions: idealized influence, inspirational motivation, intellectual stimulation and individual consideration". It can improve organizational performance by maximizing the work passion and potential of employees [13]. Since Burns put forward the transformational leadership theory, it has occupied the core position of leadership theory research. Bernard M. Bass actively developed this theory and introduced it into the study of organizational behavior. Many scholars, including Bernard M. Bass \& Avolio [13] and so on, demonstrated the relationship between transformational leadership and organizational commitment, job satisfaction, motivation, and performance. In recent studies, scholars tend to discuss transformational leadership in a variety of specific situations and use a contingency perspective to verify the role of the theory in various cultural and organizational environments.
Chaoping \& Kan based on the analysis of China's situation, divided the transformational leadership into four subdimensions: vision incentive, leadership charm, moral model and personalized care, and developed the transformational leadership scale suitable for China's situation. As the transformational leadership theory has a positive impact on organizational commitment, employee satisfaction with leadership, work motivation and other indicators of organizational performance improvement, this study reasonably speculates that this type of leadership can promote employees to evaluate the effectiveness of leadership or sacrifice their interests for the benefit of the organization, to play a positive role in the crisis of the organization [14] (Figure 1).

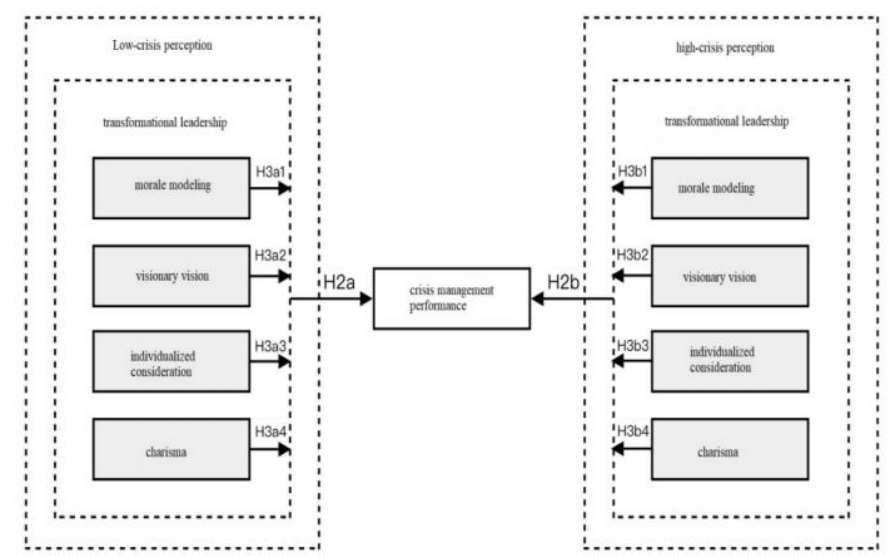

Fig. 1. Conceptual models affect crisis management performance [14].

The global competition in this era requires readiness, in particlar in this Covid-19 pandemic condition that is still surging in the world, including in Indonesia health sector. This study aimed to measure the effect of transformational leadership on employees' performance of the employee of a hospital in Indonesia. Survey was done in one of the bussiets hosptial in greater Jakarta area using simple random sampling technique and the returned and valid questionnaire results were 154 samples. Data processing was used SEM method with SmartPLS 3.0 software. The results of this study concluded that transformational leadership have not significant effect on the employees' performance, but transformational leadership have a positive and significant effect on readiness to change. Findings also revealed that readiness to change have a positive and significant effect on relationship between transformational leadership and employees' performance. This study also confrimed that readiness to change as fully mediator. This new research proposed a model for building employees' performance among the employee of a hospital in Indonesia through enhancing transformational leadership practice with readiness to change as a mediator [15].

In this study, from the perspective of epidemic crisis scenarios, based on the transformational leadership theory, it has been demonstrated that under different epidemic crisis perceptions, transformational leadership has a significant positive correlation with crisis management performance. 
At the same time, under low epidemic crisis perceptions, moral modeling and charisma have a significant positive correlation with crisis management performance. Under the epidemic crisis perception, Visionary vision and charisma have a significant positive correlation with crisis management performance, but moral modeling has lost its correlation [14].

\section{CONCLUSIONS}

Bass concludes that research evidence more clearly shows that transformational leadership can move followers to exceed expected performance. Transformational leadership gives rise to greater effort, commitment, and satisfaction of his subordinates [13].

Improving teacher teaching performance can be optimized by developing the capacity of the teacher (capacity building) itself. Capacity building is the process of improving the ability of knowledge and skills, as well as the attitudes and behavior of teachers in educational organizations. In this process it can certainly be done in various ways, both through competencybased education and training, clear career pattern development, all of which are to improve the performance of teachers in carrying out their duties. Therefore, capacity building is closely related to teacher's abilities, institutional capabilities, and organizational system capabilities [16]

Based on the results of calculating questionnaires and interviews about Transformational Leadership for improving Teacher Performance during the Covid-19 Pandemic, it is concluded that transformational leadership has implications for improving teacher performance during the Covid-19 pandemic. The higher implications of transformational leadership, the higher teacher's performance improving. The innovation and creativity efforts undertaken by transformational leaders during the Covid-19 pandemic were providing various training for teachers, including training on mastery of Information and Communication Technology (ICT), making online learning platforms, making creative learning medias, providing facilities adequate infrastructure, as well as maintaining regular communication and evaluation to solve student learning problems. The effects of innovation and creativity in transformational leadership are increasing teacher's skills in mastery of Information and Communication Technology (ICT), teachers become more creative in making learning medias, teachers are still excited about learning even without face to face with students, and communication between leaders and followers stay awake. With improving teacher's performance, it is expected that educational goals can be achieved effectively and efficiently.

\section{REFERENCES}

[1] D. Kurniasari, S. Hardhienata, and B. Rubini, "Improving Teacher Performance through Transformational Leadership Development, Pedagogic Competency, and Achievement Motivation," Int J Manag Stud Res., vol. 7, no. 12, pp. 1-8, 2019.

[2] M. Riadi, Kepemimpinan Transformasional, KajianPustaka.com, 2020 [Online] Retrieved from: www.kajianpustaka.com/2017/08/kepemimpinan-transformasional.html.

[3] W. Van Lancker and Z. Parolin, "COVID-19, school closures, and child poverty: a social crisis in the making," Lancet Public Health, vol, 5, no, 5, pp. 243-4, 2020.

[4] G. Yukl, Kepemimpinan dalam Organisasi, Edisi Kelima. Jakarta Indeks, 2009, pp. 290-305.

[5] U.S. Saud, Bunga Rampai Administrasi Pendidikan: Teori dan Praktik, Bandung: Alfabeta, 2019.

[6] B. Hariani and E. Masdupi, "The Effect of Transformational Leadership, PEP, POS and Organizational Commitment on OCB: A Literature Review”, Piceeba, vol, 97, pp. 371-8, 2019.

[7] N. Nurkolis, R. Warastuty, and Y Yuliejantiningsih, "Do Academic Supervision and Activities in MGMP (Subject Teacher Deliberations) Increase Teachers Performance?", ICERAM, 2020.

[8] D. Kurniasari, S. Hardhienata, and B. Rubini, "Improving Teacher Performance through Transformational Leadership Development, Pedagogic Competency, and Achievement Motivation,” Int J Manag Stud Res., vol. 7, no. 12, pp. 1-8, 2019.

[9] F. Reimers, A. Schleicher, J. Saavedra, and S. Tuominen, "Supporting the continuation of teaching and learning during the COVID-19 pandemic," OECD, 1-38, 2020

[10] Suwanto, Budaya Kerja Guru, Jogjakarta: Gre Publishing, 2019, 78-79p

[11] Republic of Indonesia Council, Undang-Undang Nomor 14 Tahun 2005 tentang Guru dan Dosen, 2005.

[12] F. Matriadi and R.F. Dalimunthe, "Analyzing the Compensation an Competence on Senior High School Teacher's Performance through the Mediating Role of Job Motivation," EBIC, vol. 46, pp. 612-9, 2018.

[13] M.T. Isnawati, Pengaruh Kepemimpinan transformasional Kepala Sekolah dan Motivasi Kerja Terhadap rofesionalisme Guru dan Kinerja Guru, Yogyakarta: Universitas Sanata Dharma, 2016.

[14] M. Han and Q Sheng, "How does transformational leadership work on COVID-19? An empirical evidence from China,” J Innov Stud., vol. 1, no. 2, pp. 1-20, 2020 .

[15] D. Novitasari and F.S. Goestjahjanti, "The Role of Readiness to Change between Transformational Leadership and Performance: Evidence from a Hospital during Covid-19 Pandemic,” APMBA, vol. 1, pp. 8997, 2020

[16] I. Rahmawati and J. Permana, "Improving Teachers Teaching Performances Through Development of Capacity Buildings and Innovative Work Behaviors," ICREAM, 2020. 